\title{
Role of Irrigation Regimes and City Waste Compost in Boosting Water Productivity, Root Density and Quality of Dissimilar Rice Varieties Beneath Climatic Condition of Varanasi
}

\author{
Dharminder $^{1 *}$ and Ram Kumar Singh ${ }^{2}$ \\ ${ }^{1}$ Institute of Agricultural Sciences, Banaras Hindu University, Varanasi and \\ Faculty of Agriculture, DRP-CAU, Pusa, Samastipur, India \\ ${ }^{2}$ Institute of Agricultural Sciences, Banaras Hindu University, Varanasi, India \\ *Corresponding author
}

\section{A B S T R A C T}

\section{Keywords}

Root density, protein, MSW

Water productivity, etc.

Article Info

Accepted:

04 November 2019

Available Online:

10 December 2019
A field experiment was planned and carried out with entitled "Role of irrigation regimes and city waste compost in boosting water productivity, root density and quality of dissimilar rice varieties beneath climatic condition of Varanasi"for two successive years from 2017-18 to 2018-19 at Research farm of BHU, Varanasi. This experiment was carried out in splitplot design with three replications with the objective to study root density performance and water productivity under different water regimes, varieties and city waste compost. The result revealed that irrigation scheduling at 75 mm cumulative pan evaporation and Sahbhagi had produced significantly higher root density; among the nutrient treatments, MSW compost enriched with consortia was found distinctly superior over rest of the treatments in term of root density in addition to water productivity.

\section{Introduction}

Globally rice is grown in about 150 million ha from which 497 million tonnes of rice produced annually. In Asia $90 \%$ of rice is production and consumed (Anonymous, 2015). India has the world's largest area under rice with 43.1 million ha and is the second largest producer of paddy (104.32 million tonnes), (Anonymous 2018) next to China. Within the country, rice occupies one-fourth of the total cropped area, contributes about 40 to 43 percent of total food grain production and play a vital role in the national food and livelihood security system. In UP, rice is cultivated in an area of about 5.86 million hectares with a total production of 12.50 million tonnes of rice (Anonymous, 2018). By the year 2050, the world population will increasing rapidly and may reach 6.0 to 9.3 billion, whereas the crop production is decreasing rapidly due to the negative impact 
of various biotic and abiotic stresses, including biotic stress (such as insects, bacteria, fungi, and viruses) and abiotic stress (such as drought, salinity, cold, heavy metals, and pesticides). The challenge of growing water shortage and recurrent occurrence of drought is threatening food security in the eastern region. Eastern states account for 27.26 million ha rice area, out of which nearly 4.28 million ha area is prone to regular drought.

India has just four per cent of the world's fresh water but accommodates $18 \%$ of the global population (Dharminder et al., 2019).The water-use efficiency of rice is much lower than that of other crops. On average, 2500 liter of water is used, ranging from 800 to 5000 liter to produce $1 \mathrm{~kg}$ of rough rice (Bouman, 2009). Declining water resources for rice cultivation has encouraged research on the development measures to increase water use efficiency. On the other hand, water should also be utilized proficiently for getting higher yield per unit of water applied. Thus, proper scheduling of irrigation should be aimed at abolishing over- or under- irrigation and ensuring optimum yields with regards to high water productivity.

The disposal of a great quantity of organic wastes produced by the municipal, agricultural and agro-industrial activities causes energetic, economic and environmental problems (Castaldi and Melis, 2002); but, municipal solid wastes (MSW), for their high content in organic matter and mineral elements, could be used to restore soil fertility. The urban solid waste consists of more than 40 percent of organic waste, so composting most of this waste would be the best way to reduce the quantity to one fourth resulting in nutrient-rich soil amendment. This city waste compost's nutrient value can be enhanced through microbial activity further it might be helpful for increasing the root density which is directly related to yield. Keeping above point in view present experiment was planned and conducted.

\section{Materials and Methods}

The present examination entitled "Role of irrigation regimes and city waste compost in boosting water productivity, root density and quality of dissimilar rice varieties beneath climatic condition of Varanasi" was carried out for two consecutive years 2017-18 and 2018-19 at the Agriculture Research Farm, Institute of Agricultural Sciences, Banaras Hindu University, Varanasi, Uttar Pradesh. The rice was sown as direct-seeded on $26^{\text {th }}$ June during both the years. The experiment was laid out in a split plot design. The main field consists of two factors, a-Irrigation scheduling; $50 \mathrm{~mm}$ cumulative pan evaporation $\left(\mathrm{I}_{1}\right) \& 75 \mathrm{~mm}$ cumulative pan evaporation $\left(\mathrm{I}_{2}\right)$ and b-Varieties: Swarna $\left(\mathrm{V}_{1}\right)$ \& Sahbhagi (V2) and subplot had eight treatments i.e. $100 \% \operatorname{RDF}\left(\mathrm{N}_{1}\right), 75 \% \mathrm{RDF}$ (No compost) Control $\left(\mathrm{N}_{2}\right), 75 \% \mathrm{RDF} \&$ Municipal Solid Waste compost @ 10t/ha $\left(\mathrm{N}_{3}\right), 75 \% \mathrm{RDF}$ $\&$ Enriched Municipal Solid Waste compost (NFB) @ 10t/ha $\left(\mathrm{N}_{4}\right), 75 \% \mathrm{RDF} \&$ Enriched Municipal Solid Waste compost (PSB) @ 10t/ha $\left(\mathrm{N}_{5}\right), 75 \%$ RDF \& Enriched Municipal Solid Waste compost (ZSB)@ 10t/ha $\left(\mathrm{N}_{6}\right)$, 75\%RDF \& Enriched Municipal Solid Waste compost (Trichoderma sp.) @ 10t/ha $\left(\mathrm{N}_{7}\right)$, 75\%RDF \& Enriched Municipal Solid Waste compost (Consortia bio-inoculants) @ 10t/ha $\left(\mathrm{N}_{8}\right)$. The RDF used at the rate of $120 \mathrm{~kg}$ nitrogen, $60 \mathrm{~kg}$ phosphorus, $60 \mathrm{~kg}$ potash and $20 \mathrm{~kg}$ zinc sulphate per hectare. Municipal solid waste compost was used at rate $10 \mathrm{tha}^{-1}$ before sowing and after mixing with respective bio inoculants. Irrigation to both varieties was given as per treatment of irrigation scheduling; one after $50 \mathrm{~mm}$ of cumulative pan evaporation (CPE) and second after $75 \mathrm{~mm}$ of CPE. The five-centimetre irrigation was applied at each time. The 
periodical data on root was taken. The Water productivity was worked out use the below given formula:

Water productivity $(\mathrm{kg} / \mathrm{m} 3$ water)

Grain yield (kg/ha)

Water applied (m3/ha)

The periodical raw root density was worked at 30 days interval from the experimental plot as per treatment. The root length was taken from five random locations from the distinguish plots. There after average plant root volume was calculated by water displacement method. The root dry weight was calculated after sundry in addition to oven dry at $75{ }^{\circ} \mathrm{C}$ (constant weight). Then root density was calculated using the formula mass over volume.

\section{Results and Discussion}

The irrigation scheduling had its impact during both the years of experiment as well as on mean basis also. During first year of experiment irrigation after $75 \mathrm{~mm}$ of CPE was found significantly superior in term of water productivity over $50 \mathrm{~mm}$ of CPE nevertheless in 2018 irrigation after $50 \mathrm{~mm}$ of CPE recorded statistically higher water productivity compared to $75 \mathrm{~mm}$ of CPE. However, on the mean basis, the application of irrigation after $75 \mathrm{~mm}$ of CPE had achieved a significant variation.

Amid the varieties, Swarna had proved its supremacy above Sahbhagi in term of water productivity for the whole period of crop study in addition to two years means basis. Between subplot treatments, application of 75\%RDF \& E-MSWC (Consortia) @ 10t/ha had outperformed the rest of the treatments with regard to water productivity except 75\%RDF \& E- MSWC (Trichoderma) @ 10t/ha in first and second year of experiment and also on mean basis.
At 90 DAS data echoed that application of irrigation after $75 \mathrm{~mm}$ of CPE resulted in significantly higher root density compared to $50 \mathrm{~mm}$ of CPE in the first and second year of study; on two years mean basis also it found significantly higher root density. Likewise, Sahbhagi root density was also significantly higher compared to Swarna in respected years of crop study besides mean basis.

Among subplot treatments, significantly higher root density was recorded with application of $75 \% \mathrm{RDF} \quad \& \quad \mathrm{E}-\mathrm{MSWC}$ (Consortia)@10t/ha which was statistically superior over rest of the treatment except 75\%RDF \& E-MSWC (Trichoderma) @ $10 t /$ ha in first the years of study as well as in the second year and also two years mean basis. A similar trend of root density was observed at harvest. The irrigation scheduling fall short to gain significant difference in grain nitrogen content; during first as well as in the second year and also on two years mean basis.

However, Sahbhagi had achieved the significantly higher grain nitrogen content during the whole period of crop study in addition to the mean basis. Among nutrients, significantly higher grain nitrogen content was found; which was significantly higher over rest the treatment of subplot except 75\%RDF \& E- MSWC (NFB) @ 10t/ha.

The data relevant with respect to protein content in grain was dissect and it confirms that irrigation scheduling failed to generate a significant difference in protein content of grain during initial \& final year and also on two years mean basis.

However, varieties had exerted significant difference in protein content; Sahbhagi had statistically higher protein content compared to Swarna on individual year basis and also on two years mean basis.

Amid nutrient treatment, use of $75 \%$ RDF \& 
E-MSWC (Consortia) @ 10t/ha eyewitness the statistically higher protein content in grain during whole period of experiment in addition to two year basis which was statistically significant over remaining treatments of subplots except $75 \%$ RDF \& E- MSWC (NFB) @ $10 \mathrm{t} / \mathrm{ha}$, in both the years of trial and on two years mean basis also.

\section{Water productivity}

In general, water productivity is worked out as grain yield divided by water used; being less amount of water was used in $75 \mathrm{~mm}$ of CPE hence, it outcome as higher water productivity.

The experimental finding comfirmed by Hamoud et al., (2018) they reported the highest total water productivity with $90 \%$ of saturation and $30 \mathrm{~mm}$ flooded over $100 \%$ of saturation and $30 \mathrm{~mm}$ flooded.

During second year of experiment the higher water productivity was recorded with $50 \mathrm{~mm}$ of CPE; the explanation behind that during 2018, rainfall distribution pattern was uniformed compared to 2017 rainfall, in addition to higher amount rainfall, due to this cause grain yield was higher which resulted in higher water productivity. This result is in confirmation with the findings of Narolia et al., 2014.

The water productivity of Swarna was distinctly higher than Sahbhagi might be due to higher yield and yield attribute of Swarna, Swarna has significantly higher grain yield than Sahbhagi that's why Swana has higher water productivity; this result are in verification with Zhang et al., 2012.

The highest water productivity was also recorded with 75\%RDF \& E-MSWC (Consortia)@10t/ha. This might be due combine effect of all microorganisms; they not only smooth the progress of mineralization but also help root development at same time Trichoderma make root vicinity free from pathogen (Harman, 2000). The experimental finding is in affirmation with Shafei et al., 2008.

\section{Root density}

Irrigation scheduling with $75 \mathrm{~mm}$ of CPE had resulteded the maximum root density. Irrigation scheduling with $75 \mathrm{~mm}$ of CPE had higher root density might be due to low soil moisture; roots have penetrated to deeper soil profile in search of water for its metabolic activity and to met the evapotranspiration demand. These findings are in confirmation with Babapoor et al., 2015; they concluded that root dry weight was higher with $100 \%$ CPE than $70 \%$ and $60 \%$.

The significant higher plant density was obtained with use of 75\%RDF \& E-MSWC (Consortia) @ 10t/ha which was statistically at par with 75\%RDF \& E- MSWC (Trichoderma) @ 10t/ha; the possible reason behind this; Trichoderma have the ability to diminish the severity of plant diseases by hindering plant pathogens, mainly in the soil or on plant roots, through their high antagonistic potential (Viterbo and Horwitz, 2010; Grover et al., 2011).

\section{Quality of rice}

The higher protein content was recorded in Sahbhagi due to higher nitrogen content. Irrigation scheduling was unable to leave any impact on protein content of rice grain. The highest contents of nitrogen was recorded with 75\%RDF \& E-MSWC (Consortia) @ 10t/ha which remains statistically at par with 75\%RDF \& E- MSWC (NFB) @ 10t/ha, $75 \%$ RDF. 
Table.1 Effect of irrigation scheduling, varieties and nutrient on water productivity.

\begin{tabular}{|c|c|c|c|c|}
\hline \multirow{2}{*}{\multicolumn{2}{|c|}{$\begin{array}{l}\text { Treatments } \\
\text { Main Plot (A- Irrigation x B- Varieties) }\end{array}$}} & \multicolumn{3}{|c|}{ Water Productivity $\left(\mathrm{kg} / \mathrm{m}^{3} \mathrm{H}_{2} \mathrm{O}\right.$ Used) } \\
\hline & & \multirow[t]{2}{*}{2017} & \multirow[t]{2}{*}{2018} & \multirow[t]{2}{*}{ Mean } \\
\hline $\mathbf{A}$ & Irrigation scheduling $(5 \mathrm{~cm})$ & & & \\
\hline $\mathbf{I}_{1}$ & $50 \mathrm{~mm}$ CPE & 0.478 & 0.454 & 0.466 \\
\hline \multirow[t]{3}{*}{$\mathbf{I}_{2}$} & $75 \mathrm{~mm} \mathrm{CPE}$ & 0.512 & 0.449 & 0.481 \\
\hline & SE m+ & 0.005 & 0.005 & 0.004 \\
\hline & $\mathrm{CD}(\mathrm{P}=.05)$ & 0.016 & 0.019 & 0.013 \\
\hline B & Varieties & & & \\
\hline $\mathbf{V}_{1}$ & Swarna & 0.511 & 0.472 & 0.491 \\
\hline \multirow[t]{3}{*}{$\mathbf{V}_{2}$} & Sahbhagi & 0.479 & 0.431 & 0.455 \\
\hline & $\mathrm{SE} \mathrm{m}+$ & 0.005 & 0.005 & 0.004 \\
\hline & $\mathrm{CD}(\mathrm{P}=.05)$ & 0.016 & 0.019 & 0.013 \\
\hline $\mathbf{C}$ & Sub-plot: Nutrient & & & \\
\hline $\mathbf{N}_{1}$ & $100 \% \mathrm{RDF}$ & 0.474 & 0.444 & 0.459 \\
\hline $\mathbf{N}_{2}$ & 75\%RDF (No compost) Control & 0.401 & 0.361 & 0.381 \\
\hline $\mathbf{N}_{3}$ & 75\%RDF \& MSWC @ 10t/ha & 0.472 & 0.431 & 0.452 \\
\hline $\mathbf{N}_{4}$ & $\begin{array}{l}75 \% \text { RDF \& E- MSWC (NFB) @ } \\
10 t / h a\end{array}$ & 0.515 & 0.474 & 0.494 \\
\hline $\mathbf{N}_{\mathbf{5}}$ & 75\%RDF \& E-MSWC (PSB) @ 10t/ha & 0.513 & 0.465 & 0.489 \\
\hline $\mathbf{N}_{6}$ & 75\%RDF \& E- MSWC (ZSB)@ 10t/ha & 0.503 & 0.451 & 0.477 \\
\hline $\mathbf{N}_{7}$ & $\begin{array}{l}\text { 75\%RDF \& E- MSWC (Trichoderma) } \\
\text { @ 10t/ha }\end{array}$ & 0.535 & 0.487 & 0.511 \\
\hline \multirow[t]{7}{*}{$\mathbf{N}_{8}$} & $\begin{array}{l}\text { 75\%RDF \& E-MSWC (Consortia) @ } \\
\text { 10t/ha }\end{array}$ & 0.548 & 0.501 & 0.525 \\
\hline & $\mathrm{SE} \mathrm{m}+$ & 0.007 & 0.008 & 0.005 \\
\hline & $\mathrm{CD}(\mathrm{P}=.05)$ & 0.023 & 0.027 & 0.018 \\
\hline & I X V & NS & NS & NS \\
\hline & IX N & NS & NS & NS \\
\hline & $\mathrm{VXN}$ & NS & NS & NS \\
\hline & I X V X N & NS & NS & NS \\
\hline
\end{tabular}

MSWC: municipal solid waste compost; NFB: nitrogen fixing bacteria (Halo-Azo); PSB: phosphorus solubilizing bacteria (Halo-PSB); ZSB: zinc solubilizing bacteria (Halo-Zinc); Consortia (Halo-Mix and Trichoderma) 
Table.2 Effect of irrigation scheduling, varieties and nutrient on Root density at 90 DAS and at harvest

\begin{tabular}{|c|c|c|c|c|c|c|c|}
\hline \multicolumn{2}{|r|}{ Treatments } & \multicolumn{6}{|c|}{ Root density (g/cc) } \\
\hline & \multirow[t]{2}{*}{ Main Plot (A- Irrigation x B- Varieties) } & \multicolumn{3}{|c|}{90 DAS } & \multicolumn{3}{|c|}{ At Harvest } \\
\hline & & 2017 & 2018 & Mean & 2017 & 2018 & Mean \\
\hline A & Irrigation scheduling $(5 \mathrm{~cm})$ & & & & & & \\
\hline $\mathbf{I}_{1}$ & $50 \mathrm{~mm} \mathrm{CPE}$ & 0.221 & 0.242 & 0.232 & 0.189 & 0.166 & 0.178 \\
\hline \multirow[t]{3}{*}{$\mathbf{I}_{2}$} & $75 \mathrm{~mm} \mathrm{CPE}$ & 0.281 & 0.271 & 0.276 & 0.205 & 0.190 & 0.197 \\
\hline & SE $\mathrm{m}+$ & 0.004 & 0.009 & 0.005 & 0.002 & 0.006 & 0.003 \\
\hline & $\mathrm{CD}(\mathrm{P}=.05)$ & 0.014 & NS & 0.016 & 0.006 & 0.021 & 0.012 \\
\hline B & Varieties & & & & & & \\
\hline $\mathbf{V}_{1}$ & Swarna & 0.210 & 0.235 & 0.222 & 0.170 & 0.148 & 0.159 \\
\hline \multirow[t]{3}{*}{$\mathbf{V}_{2}$} & Sahbhagi & 0.292 & 0.279 & 0.285 & 0.224 & 0.208 & 0.216 \\
\hline & SE m+ & 0.004 & 0.009 & 0.005 & 0.002 & 0.006 & 0.003 \\
\hline & $\mathrm{CD}(\mathrm{P}=.05)$ & 0.014 & 0.033 & 0.016 & 0.006 & 0.021 & 0.012 \\
\hline $\mathbf{C}$ & Sub-plot: Nutrient & & & & & & \\
\hline $\mathbf{N}_{1}$ & $100 \% \mathrm{RDF}$ & 0.204 & 0.231 & 0.217 & 0.163 & 0.161 & 0.162 \\
\hline $\mathbf{N}_{2}$ & 75\%RDF (No compost) Control & 0.187 & 0.219 & 0.203 & 0.144 & 0.145 & 0.144 \\
\hline $\mathbf{N}_{3}$ & 75\%RDF \& MSWC @ 10t/ha & 0.234 & 0.249 & 0.241 & 0.179 & 0.161 & 0.170 \\
\hline $\mathbf{N}_{4}$ & 75\%RDF \& E- MSWC (NFB) @ 10t/ha & 0.248 & 0.250 & 0.249 & 0.198 & 0.181 & 0.189 \\
\hline $\mathbf{N}_{5}$ & 75\%RDF \& E-MSWC (PSB) @ 10t/ha & 0.263 & 0.276 & 0.269 & 0.214 & 0.188 & 0.201 \\
\hline $\mathbf{N}_{6}$ & 75\%RDF \& E- MSWC (ZSB)@ 10t/ha & 0.263 & 0.233 & 0.248 & 0.185 & 0.170 & 0.177 \\
\hline $\mathbf{N}_{7}$ & $\begin{array}{l}\text { 75\%RDF \& E- MSWC (Trichoderma) @ } \\
\text { 10t/ha }\end{array}$ & 0.301 & 0.296 & 0.298 & 0.241 & 0.208 & 0.225 \\
\hline \multirow[t]{7}{*}{$\mathbf{N}_{8}$} & $\begin{array}{l}\text { 75\%RDF \& E-MSWC (Consortia) @ } \\
\text { 10t/ha }\end{array}$ & 0.310 & 0.299 & 0.304 & 0.253 & 0.209 & 0.231 \\
\hline & SE + & 0.006 & 0.013 & 0.006 & 0.002 & 0.009 & 0.005 \\
\hline & $\mathrm{CD}(\mathrm{P}=.05)$ & 0.020 & 0.046 & 0.022 & 0.008 & 0.030 & 0.016 \\
\hline & IX V & NS & NS & NS & NS & NS & NS \\
\hline & I X N & NS & NS & NS & NS & NS & NS \\
\hline & V X N & NS & NS & NS & NS & NS & NS \\
\hline & I X V X N & NS & NS & NS & NS & NS & NS \\
\hline
\end{tabular}

MSWC: municipal solid waste compost; NFB: nitrogen fixing bacteria (Halo-Azo); PSB: phosphorus solubilizing bacteria (Halo-PSB); ZSB: zinc solubilizing bacteria (Halo-Zinc); Consortia (Halo-Mix and Trichoderma) 
Table.3 Effect of irrigation scheduling, varieties and nutrient on nitrogen content

\begin{tabular}{|c|c|c|c|c|}
\hline \multicolumn{2}{|c|}{ Treatments } & \multirow{2}{*}{\multicolumn{3}{|c|}{$\begin{array}{l}\mathbf{N} \text { content }(\%) \\
\text { Grain }\end{array}$}} \\
\hline & \multirow[b]{2}{*}{ Main Plot (A- Irrigation x B- Varieties) } & & & \\
\hline & & 2017 & 2018 & Mean \\
\hline A & Irrigation scheduling (5cm) & & & \\
\hline $\mathbf{I}_{\mathbf{1}}$ & $50 \mathrm{~mm} \mathrm{CPE}$ & 0.807 & 0.939 & 0.87 \\
\hline $\mathbf{I}_{2}$ & $75 \mathrm{~mm} \mathrm{CPE}$ & 0.768 & 0.930 & 0.85 \\
\hline & SE $\mathrm{m}+$ & 0.012 & 0.009 & 0.01 \\
\hline & $\mathrm{CD}(\mathrm{P}=.05)$ & NS & NS & NS \\
\hline B & Varieties & & & \\
\hline$V_{1}$ & Swarna & 0.661 & 0.832 & 0.75 \\
\hline $\mathbf{V}_{2}$ & Sahbhagi & 0.913 & 1.037 & 0.97 \\
\hline & SE $\mathrm{m}+$ & 0.012 & 0.009 & 0.01 \\
\hline & $\mathrm{CD}(\mathrm{P}=.05)$ & 0.043 & 0.033 & 0.03 \\
\hline $\mathbf{C}$ & Sub-plot: Nutrient & & & \\
\hline $\mathbf{N}_{1}$ & $100 \% \mathrm{RDF}$ & 0.643 & 0.779 & 0.71 \\
\hline $\mathbf{N}_{2}$ & 75\%RDF (No compost) Control & 0.529 & 0.643 & 0.59 \\
\hline $\mathbf{N}_{3}$ & 75\%RDF \& MSWC @ 10t/ha & 0.697 & 0.815 & 0.76 \\
\hline $\mathbf{N}_{4}$ & 75\%RDF \& E- MSWC (NFB) @ 10t/ha & 0.923 & 1.140 & 1.03 \\
\hline $\mathbf{N}_{5}$ & 75\%RDF \& E-MSWC (PSB) @ 10t/ha & 0.814 & 0.914 & 0.86 \\
\hline $\mathbf{N}_{6}$ & 75\%RDF \& E- MSWC (ZSB)@ 10t/ha & 0.848 & 0.991 & 0.92 \\
\hline $\mathbf{N}_{7}$ & 75\%RDF \& E- MSWC (Trichoderma) @ 10t/ha & 0.887 & 1.007 & 0.95 \\
\hline $\mathbf{N}_{8}$ & 75\%RDF \& E-MSWC (Consortia) @ 10t/ha & 0.957 & 1.187 & 1.07 \\
\hline & SE m+ & 0.018 & 0.013 & 0.01 \\
\hline & $\mathrm{CD}(\mathrm{P}=.05)$ & 0.061 & 0.046 & 0.04 \\
\hline & I X V & NS & NS & NS \\
\hline & I X N & NS & NS & NS \\
\hline & V X N & NS & NS & NS \\
\hline & I X V X N & NS & NS & NS \\
\hline
\end{tabular}

MSWC: municipal solid waste compost; NFB: nitrogen fixing bacteria (Halo-Azo); PSB: phosphorus solubilizing bacteria (Halo-PSB); ZSB: zinc solubilizing bacteria (Halo-Zinc); Consortia (Halo-Mix and Trichoderma) 
Table.4 Effect of irrigation scheduling, varieties and nutrient on protein content in grain

\begin{tabular}{|c|c|c|c|c|}
\hline \multicolumn{2}{|c|}{ Treatments } & \multicolumn{3}{|c|}{$\begin{array}{l}\text { Protein content (\%) } \\
\text { Grain }\end{array}$} \\
\hline & Main Plot (A- Irrigation x B- Varieties) & & 2018 & Mean \\
\hline A & Irrigation scheduling (5cm) & & & \\
\hline $\mathbf{I}_{1}$ & $50 \mathrm{~mm}$ CPE & 5.04 & 5.87 & 5.46 \\
\hline \multirow[t]{3}{*}{$\mathbf{I}_{2}$} & $75 \mathrm{~mm} \mathrm{CPE}$ & 4.80 & 5.81 & 5.30 \\
\hline & SE m+ & 0.08 & 0.06 & 0.05 \\
\hline & $\mathrm{CD}(\mathrm{P}=.05)$ & NS & NS & NS \\
\hline B & Varieties & & & \\
\hline $\mathbf{V}_{1}$ & Swarna & 4.13 & 5.20 & 4.67 \\
\hline \multirow[t]{3}{*}{$\mathbf{V}_{2}$} & Sahbhagi & 5.71 & 6.48 & 6.09 \\
\hline & SE m+ & 0.08 & 0.06 & 0.05 \\
\hline & $\mathrm{CD}(\mathrm{P}=.05)$ & 0.27 & 0.20 & 0.17 \\
\hline C & Sub-plot: Nutrient & & & \\
\hline $\mathbf{N}_{1}$ & $100 \%$ RDF & 4.02 & 4.87 & 4.44 \\
\hline $\mathbf{N}_{2}$ & 75\%RDF (No compost) Control & 3.30 & 4.02 & 3.66 \\
\hline $\mathbf{N}_{3}$ & 75\%RDF \& MSWC @ 10t/ha & 4.36 & 5.10 & 4.73 \\
\hline $\mathbf{N}_{4}$ & 75\%RDF \& E- MSWC (NFB) @ 10t/ha & 5.77 & 7.16 & 6.46 \\
\hline $\mathbf{N}_{5}$ & 75\%RDF \& E-MSWC (PSB) @ 10t/ha & 5.09 & 5.71 & 5.40 \\
\hline $\mathbf{N}_{6}$ & 75\%RDF \& E- MSWC (ZSB)@ 10t/ha & 5.30 & 6.19 & 5.75 \\
\hline $\mathbf{N}_{7}$ & 75\%RDF \& E- MSWC (Trichoderma) @ 10t/ha & 5.54 & 6.29 & 5.92 \\
\hline \multirow{7}{*}{$\mathbf{N}_{8}$} & 75\%RDF \& E-MSWC (Consortia) @ 10t/ha & 5.98 & 7.38 & 6.68 \\
\hline & $\mathrm{SE} \mathrm{m}+$ & 0.11 & 0.08 & 0.07 \\
\hline & $\mathrm{CD}(\mathrm{P}=.05)$ & 0.38 & 0.29 & 0.24 \\
\hline & IX V & NS & NS & NS \\
\hline & I X N & NS & NS & NS \\
\hline & V X N & NS & NS & NS \\
\hline & I X V X N & NS & NS & NS \\
\hline
\end{tabular}

MSWC: municipal solid waste compost; NFB: nitrogen fixing bacteria (Halo-Azo); PSB: phosphorus solubilizing bacteria (Halo-PSB); ZSB: zinc solubilizing bacteria (Halo-Zinc); Consortia (Halo-Mix and Trichoderma)

Owing to enrichment with microorganism, this efficiently mineralized the nutrient, which was readily absorbed by crop and translocated to seed. The experimental findings are in confirmation with Adzmi et al., 2014

The application of $75 \%$ RDF \& E-MSWC (Consortia) @ 10t/ha was found superior in terms of water productivity and root density, however it was equal with $75 \%$ RDF \& EMSWC (NFB) @ 10t/ha with respect to nitrogen content as well as protein content.
Higher water productivity and root density was resulted with irrigation after $75 \mathrm{~mm}$ of CPE found. The Swarna was better performer related with water productivity whereas Sahbhagi proved it superiority in terms of root density, nitrogen content and protein content in grain.

\section{References}

Anonymous 2018. Agriculture - Statistical Year Book India, Government of India, 
Ministry of statistics and programme implementation.

http://www.mospi.gov.in/statisticalyear-book-india/2018/177

Anonymous, 2015. Indian Institute of Rice Research, Vision 2050, Indian Council of Agricultural Research Rajendranagar, Hyderabad 500 030, Telangana State.

Dharminder, Singh, R.K. Kumar, V., Devedee, A.K., Mruthyunjaya, M. and Bhardwaj, R., 2019. The clean water: The basic need of human and agriculture, International Journal of Chemical Studies, 7(2), 1994-1998.

Bouman, B.A.M, 2009. How much water does rice use? Rice Today, 8,28-29, 2009.

Castaldi P, and Melis P. 2002. Composting of Posidonia oceanica and its use in agriculture. New York: Springer.

Hamoud, Y.A., Guo, X., Wang, Z., Chen, S. \& Rasoul, G. 2018. Effects of irrigation water regime, soil clay content and their combination on growth, yield, and water use efficiency of rice grown in South China. International Journal of Agricultural and Biological Engineering, 11(4), 144-155.

Narolia, R.S., Singh, P., Prakash, C. and Meena, H. 2014. Effect of irrigation schedule and weed-management practices on productivity and profitability of direct-seeded rice (Oryza sativa) in South-eastern Rajasthan. Indian Journal of Agronomy, 59 (3),
398-403.

Zhang,Y., Tang, Q, Peng, S., Xing, D., Qin,J., Laza, R.C. and Punzalan, B.R. 2012. Water Use Efficiency and Physiological Response of Rice Cultivars under Alternate Wetting and Drying Conditions, The Scientific World Journal, 2012:10.

Harman, G.E. 2000. Myths and Dogmas of biocontrol, Changes in perceptions derived from research on Trichoderma harzianum T-22. Plant Diseases, 84, 377-393.

Shafei1, A., Yehia, M. and Naqib, F. 2008. Impact of effective microorganisms compost on soil fertility and rice productivity and quality, Misr Journal of Agriculture Engineering, 25(3), 10671093.

Babapoor, E., Soltani, J., Varavipour, M. and Asadi, R. 2015. Effect of irrigation and nitrogen management on rice root and yield. Crop Research, 49(1, 2 \& 3), 1-7.

Viterbo, A. and Horwitz, B.A. 2010. Mycoparasitism. In: Cellular and Molecular Biology of Filamentous Fungi, 42, 676-693, American Society for Microbiology, Washington, USA.

Grover, M., Ali, S.K.Z., Sandhya, V., Rasul, A. and Venkateswarlu, B.2011. Role of microorganisms in adaptation of agriculture crops to abiotic stresses. World Journal of Microbiology and Biotechnology, 27, 1231-1240.

\section{How to cite this article:}

Dharminder and Ram Kumar Singh 2019. Role of Irrigation Regimes and City Waste Compost in Boosting Water Productivity, Root Density and Quality of Dissimilar Rice Varieties Beneath Climatic Condition of Varanasi. Int.J.Curr.Microbiol.App.Sci. 8(12): 2995-3003. doi: https://doi.org/10.20546/ijcmas.2019.812.348 